\title{
VAIKUTTAVAAN KOULUTUKSEEN
}

Robinson, D.G. - Robinson, J.C., 1989. Training for impact. How to link training to business needs and measure the results. San Francisco: Jossey-Bass.

Koulutuksen laatuun ja vaikutuksiin kiinnitetään yhä enemmän huomiota. Tällainen tilivelvollisuuden ja tulosvastuullisuuden korostuminen näkyy selkeimmin profittyyppisten organisaatioiden henkilöstökoulutuksessa. Suurissa organisaatioissa on omat koulutusyksiköt ja pienemmät käyttävät hyväkseen ulkopuolista koulutusasiantuntemusta. Organisoitiinpa koulutus kuinka tahansa, yritysjohto on herkkä tivaamaan näyttöä koulutuksen tuloksellisuudesta.

Robinsonit ovat pitkän kokemuksen omaavia henkilöstökoulutuksen konsultteja 'suuresta maailmasta', josta suomalainenkin koulutus ottaa malleja. Robinsoneiden viime vuonna ilmestynyt teos sopii mielestäni yhdeksi malliksi henkilöstökoulutuksen arviointihankkeisiin. Ohuenlaisesta teoreettisesta otteesta huolimatta teos sopii sekä yliopistollisiin aineopintoihin että käytännön kouluttajalle käsikirjaksi. Teos on johdonmukainen esitys henkilöstökoulutuksen laaja-alaisesta arvioinnista. Samalla se antaa monia arvokkaita viitteitä sellaisen henkilöstökoulutuksen suunnittelemiseksi, jolla voi odottaa olevan sekä oppivan yksilön että koko organisaation tasolla näkyviä koulutusvaikutuksia.

Kirjoittajat korostavat sekä kouluttajan että yritysjohdon vastuuta tuloksellisen koulutuksen aikaansaamisessa. Kouluttajan vastuulla on onnistuneiden oppimiskokemusten aikaansaaminen.

Johdon vastuulla on työympariston muokkaaminen sellaiseksi, että koulutuksessa hankitut tiedot ja taidot pääsevät elämään ja että uusin eväin työhönsä orientoituva saa vahvistusta ja tarvitessaan lisää ohjausta ja opastusta. Kun sekä oppimiskokemukset että työympäristö ovat optimaalisia, voidaan odottaa yrityksen ja organisaation toiminta-ajatuksen mukaisia tuloksia.

Kouluttajan ja koulutussuunnittelijan on tarkistettava rooliaan ja tehtäviään. Suunnittelussa on panostettava tarveanalyyseihin ja rutiininomaisista koulutuksen järjestelytehtävistä on suuntauduttava entistä aktiivisempaan yhteistyöhön koulutuksen tilaajien kanssa sekä koulutuksen systemaattiseen ja laaja-alaiseen arviointiin. Yritysjohto on saatava tajuamaan, että myös heillä on oma vastuunsa koulutuksen onnistumisesta - sitä ei voi sysätä vain koulutusammattilaisille. 
Edellä kuvatun perusidean - kouluttajan ja johdon välisen 'asiakassuhteen' - varassa etenee Robinsoneiden oppi- ja käsikirjamainen kuvaus koulutuksen arvioinnin eri vaiheista ja niissä sovellettavista metodeista. Tarveanalyyseja ja 'asiakassuhteen' muodostamista koskevien ohjeiden jälkeen he erittelevät arvioinnin kohteet neljään peräkkäiseen vaiheeseen.

Ensimmäisenä on ns. reaktioarviointi, eräänlaisen asiakkaan tyytyväisyysindeksin laskeminen. Käytännössä tämä merkitsee henkilöstökoulutuksesta hyvin tuttua kurssikritiikkiä, joka tavallisesti tapahtuu kurssin lopulla täytettävän kurssiarviointilomakkeen avulla. Tällaista 'happy tai smile sheet' -tyyppistä mittausta tekijät analysoivat kriittisesti. He toteavat kuitenkin tällaisen arvioinnin oikeutuksen ja antavat hyviä ohjeita kurssiarvioinnin kehittämiseksi.

Toisena vaiheena on oppimisen arviointi, jota kirjoittajien mukaan harrastetaan mielestäni yllättävänkin runsaasti amerikkalaisessa henkilöstökoulutuksessa. Nimittäin kirjoittajat esittävät tuloksia, joiden mukaan peräti lähes puolessa firmojen koulutusta on tavalla tai toisella tietoista oppimisen arviointia. Suomalaisessa aikuiskoulutuksessa systemaattinen oppimisen arviointi on nähdäkseni toistaiseksi huomattavasti harvinaisempaa. Kirjoittajien mukaan oppimisen arvioinnilla saadaan esille koulutusohjelman laatutaso.

Kolmantena arviointikohteena kirjassa esitellään sekä havaittavat että ei-havaittavat käyttäytymisen ja toiminnan muutokset. Tämän tason tulosten arviointi edellyttää jo koulutuksen jälkeisessä ajassa tapahtuvia mittauksia. Kirjoittajat puhuvatkin koulutustulosten jäljit- tämisestä (tracking) ja esittelevät jopa kokeellisia ja ei-kokeellisia ennen-silloin-jälkeen -asetelmia muutosvaikutusten arvioimiseksi.

Neljännen tason tai vaiheen arvioinnista kirjoittajat käyttävät termiä 'vaikutus- tai tulosevaluointi'. Kyse on nimenomaan organisaation tasolla näkyvistä vaikutuksista, varsinaisesta koulutuksen vaikuttavuudesta. Kirjoittajat toteavat meille monille jo niin tutun asian: koulutuksen omavaikutuksia on erittäin vaikea tai mahdoton eristää monien tekijöiden yhteisvaikutuksista. Tärkeintä olisikin päästä sellaiseen tilanteeseen, jossa voisi suhteellisen luotettavasti todeta, että koulutus on ollut osaltaan vaikuttamassa organisaation tai yrityksen toiminta-ajatuksen kannalta tärkeiden tulosten muodostumiseen.

Noihin evaluoinnin eri vaiheisiin Robinsoneiden teos antaa monia hyödyllisiä vinkkejä. Kirjoittajat kannustavat panostamaan nimenomaan kolmannen ja neljännen vaiheen kehittämiseen, jotka amerikkalaisessakin henkilöstökoulutuksessa ovat vielä varsin vähän esillä. Niistä olisi kuitenkin arviointitietoa hankittava, mikäli halutaan vastata lisääntyviin kysymyksiin koulutuksen hyödystä ja vaikutuksista. Uskon Robinsoneiden kirjoittaneen kirjansa ohjatakseen HRD-ammattilaisten, kuten he koulutusvastuuhenkilöitä nimittävät, huomion systemaattisen arvioinnin merkitykseen koulutustuotteen laadun parantamiseksi. Allekirjoitan tämän näkemyksen samoin kuin senkin, että koulutuksen tilaaja on saatava aikaisempaa paremmin mukaan vaikuttavaan koulutukseen pyrittäessä.

\section{TAPIO VAHERVA}

